\title{
PROGRAM KEMITRAAN UNIVERSITAS (PKU) BAGI KADER DI DESA DONOROJO MERTOYUDAN MAGELANG
}

\author{
Robiul Fitri Masithoh*, Sigit Priyanto \\ Staf Pengajar FIKES \\ Universitas Muhammadiyah Magelang \\ email : robiulfitri83@ummgl.ac.id
}

\begin{abstract}
The Cadres who handling the" Posyandu lansia "are still not exposed in the use of their own blood sugar level gauges so that they cannot detect in the patient's condition hypoglycemia or hyperglycemia. The purpose of this activity is to train, practice and assist cadres in using blood sugar levels in detecting elderly people with hypoglycemia or hyperglycemia in the village of Donorojo Mertoyudan Magelang. The method used for implementation of this activity was the method of community empowerment with the Participatory Rural Appraisal model, which is an approach method in the process of empowerment and increasing community participation, which is sensitive to community involvement in the overall activities carried out. The results of this service activity were carried out for five months, namely through the stages of preparation, counseling, training and mentoring. The results obtained were cadres who were able to practice using blood sugar levels and were able to detect hypoglycemia and hyperglycemia conditions. The range of early activities will be published in several mass media and community service journals. The conclusion are activity was achieved in view of the increased understanding and skills in carrying out the activity of checking blood sugar levels during and efforts to manage the increase in blood sugar levels / early detection of diabetes mellitus
\end{abstract}

Keywords: elderly posyandu, hypoglycemia, diabetes mellitus

\begin{abstract}
Abstrak
Kader yang menangani Posyandu lansia masih belum terpapar dalam penggunaan alat pengukur kadar gula darah sendiri sehingga belum bisa mendeteksi dalam kondisi pasien terjadi hipoglikemia maupun hiperglikemia. Tujuan dari kegiatan ini adalah untuk melatih, mempraktekan dan pendampingan para kader dalam penggunaan alat pengukur kadar gula darah dalam mendeteksi para lansia penderita hipoglikemia mauputn hiperglikemia di desa Donorojo Mertoyudan Magelang. Metode yang akan digunakan untuk pelaksnaan kegiatan ini adalah metode pemberdayaan masyarakat dengan model Participatory Rural Apraisal yaitu suatu metode pendekatan dalam proses pemberdayaan dan peningkatan partisipasi masyarakat, yang penekaanannya pada keterlibatan masyarakat dalam keseluruhan kegiatan yang dilaksanakan. Hasil kegiatan pengabdian ini dilakuakan selama lima bulan pelaksaan yaitu mellaui tahap persiapan, penyuluhan, pelatihan dan pendampingan. Hasil yang diperoleh yaitu para kader sudah bisa mempraktekan dalam penggunaan alat pengukur kadar gula darah dan sudah bisa mendeteksi kondisi hipoglikemia dan hiperglikemia. Luaran kegiatan dini akan dipublikasi di beberapa media massa dan jurnal pengabdian masyarakat. Kesimpulan adalah kegiatan ini berhasil dicapai dilihat dari meningkatnya pemahaman dan keterampilan dalam pelaksanaan kegiatan pengecekan kadar gula darah sewaktu dan upaya penatalaksaan dari kenaikan kadar gula darah/ deteksi dini diabetes melitus.
\end{abstract}

Kata Kunci: posyandu lansia, hipoglikemia, diabetes mellitus 


\section{PENDAHULUAN}

Meningkatnya usia harapan hidup dapat memberikan suatu gambaran kesehatan dalam suatu Negara. Oleh karena itu, kesehatan perlu ditingkatkan dan dipelihara kualitasnya. Untuk mewujudkan hal tersebut, pemerintah telah mencanangkan visi "Indonesia Sehat 2010". Dalam visi tersebut mencakup seluruh lapisan masyarakat tidak terkecuali lansia.

Lansia umumnya mengalami kemunduran mental-psikologik. Dalam penelitian, menunjukkan lansia yang terjangkit "penyakit lupa" mencapai 50,3 persen, kesepian $(20,4)$, sulit tidur $(21,3)$ dan depresi. Gejala tersebut merupakan gejala dini kelainan mental (demensia) Alzheimer. Para lansia umumnya juga mengalami ganguan kemampuan dan kemandirian untuk melakukan kegiatan sehari-hari (Hsieh, Yang, Lin, Chien, \& Kuo, 2017).WHO mengidentifikasikan lansia sebagai kelompok masyarakat yang mudah terserang kemunduran fisik dan mental (Roger, 2003).

$\begin{array}{ccc}\text { Seiring } & \text { dengan } & \text { semakin } \\ \text { meningkatnya } & \text { populasi } & \text { lansia, }\end{array}$
pemerintah telah merumuskan berbagai kebijakan pelayanan kesehatan usia lanjut ditujukan untuk meningkatkan derajat kesehatan dan mutu kehidupan lansia untuk mencapai masa tua bahagia dan berdaya guna dalam kehidupan keluarga dan masyarakat sesuai dengan keberadaannya. Sebagai wujud nyata pelayanan sosial dan kesehatan pada kelompok usia lanjut ini, pemerintah telah mencanangkan pelayanan pada lansia melalui beberapa jenjang. Pelayanan kesehatan di tingkat masyarakat adalah Posyandu lansia dan pelayanan kesehatan tingkat dasar lansia adalah Puskesmas.

Dari hasil observasi awal di desa Donorojo terdapat sejumlah 45 lansia dengan prosentase $\pm 9 \%$ dari jumlah penduduk. Adapun penyakit yang sering dikeluhkan warga meliputipenyakit kronis diantaranya diabetes melitus. Dari jumlah lansia tersebut kebanyakan tidak memiliki aktivitas, hanya duduk-duduk di rumah saja, meskipun masih ada yang melakukan aktivitas misalnya; mengasuh cucu, menganyam keranjang atau pergi ke sawah.

Jenis pelayanan kesehatan yang ada di desa tersebut dilakukan oleh bidan desa tetapi fokus pada masalah ibu dan anak. Pelayanan kesehatan yang lainnya berada di Puskesmas Mertoyudan 1 yang berjarak sekitar $1 \mathrm{~km}$ dari Desa Donorojo tersebut. Kader yang menangani Posyandu lansia masih belum terpapar dalam penggunaan alat pengukur kadar gula darah sendiri sehingga belum bisa mendeteksi dalam kondisi pasien terjadi hipoglikemia maupun hiperglikemia.

\section{METODE PENGABDIAN}

Metode yang akan digunakan untuk pelaksnaan kegiatan ini adalah metode pemberdayaan masyarakat dengan model Participatory Rural Apraisal yaitu suatu metode pendekatan dalam proses pemberdayaan dan peningkatan partisipasi masyarakat, yang penekaanannya pada keterlibatan masyarakat dalam keseluruhan kegiatan yang dilaksanakan. Prosedur kerja kegiatan pengabdian pada masyarakat ini adalah sebagai berikut: tahap persiapan dengan menyampaiakn permnohonana ijin kepada kepala desa Donorojo dan menyiapkan media yang akan dipakai dalam pelatihan dan pendampingan tersebut. Tahap selanjutnya adalah pelaksanaan yaitu dengan sosialisasi kegiatan tentang pelaksanaan kegiatan pengukuran kadar gula darah dengan menggunakan pengukur kadar gula daraj sewaktu yang akan dilaksanakan di desa tersebut. Kemudian tahapan selanjutnya adalah pendampingan. Pendampingan ini akan dilakukan dua minggu. Dan tahapan 
terakhir adalah penyuunsna laporan kemajuan dana dilanjutkan dengan penyusunan laporan akhir.

\section{HASIL DAN PEMBAHASAN}

Kegiatan pengabdian pelatihan penggunaan alat pengukur kadar gula darah ini dilakukan dengan sasaran kader yang berada di desa Donorojo Kabupaten Magelang. Peserta yang mengikuti kegiatan ini adalah para kader yang aktif dalam kegiatan posyandu lansia di dusun Krombangan Desa Donorejo kabupaten Magelang. Hasil dari kegiatan ini para kader sudah bisa melakukan pengecekan dengan alat tersebut dengan sendiri. Sehingga peserta antusias untuk mengikuti pengabdian selanjutnya.

\section{KESIMPULAN}

Tujuan dari kegiatan ini berhasil dicapai dilihat dari meningkatnya pemahaman dan keterampilan dalam pelaksanaan kegiatan pengecekan kadar gula darah sewaktu dan upaya penatalaksaan dari kenaikan kadar gula darah/ deteksi dini diabetes melitus. Dengan demikian, pelatihan dapat dikatakan berhasil karena mampu meningkatkan kemampuan dan pengetahuan peserta.

Secara keseluruhan tujuan dari pelatihan ini berhasil dicapai. Berdasarkan survei awal, sebagian besar para kader posyandu lansia masih belum bisa terkait dengan pengecekan kadar gula darah. Namun setelah diberi treatment berupa pelatihan ini, peserta mampu melakukan pengecekan pada penderita diabetes melitus.

\section{DAFTAR PUSTAKA}

[1]. Hsieh, M., Yang, J., Lin, W., Chien, H., \& Kuo, M. (2017). ScienceDirect Fasting sugar , blood pressure, and uric acid are factors related to positive proteinuria and an impaired eGFR. Journal of the Chinese Medical Association, 80(12), 782789.

https://doi.org/10.1016/j.jcma.201 $\underline{6.11 .011}$

[2]. Nasrul Efendi, 1998, Dasar-Dasar Keperawatan Kesehatan Masyarakat, Penerbit EGG, Jakarta.

[3]. Pinto, D., Fernandes, D. S., Sônia, M., Duarte, L., Pessoa, M. C., Castro, C., \& Ribeiro, A. Q. (2017). Evaluation Of Diet Quality Of The Elderly And Associated Factors. Archives of Gerontology and Geriatrics. https://doi.org/10.1016/j.archger. 2017.05.006

[4]. Suwoko,Drs.SH, 2004, Lansia Indonesia Tercepat artikel dalam (Suara Merdeka, Sabtu, 29 Mei 2004. WACANA, hal 6).

[5]. Wahyudi Nugroho, 2000, Keperawatan Gerontik Edisi 2, Penerbit EGC, Jakarta. 